\title{
Lactobacillus crispatus BC1 Biosurfactant Counteracts the Infectivity of Chlamydia trachomatis Elementary Bodies
}

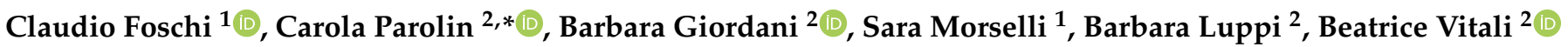 \\ and Antonella Marangoni ${ }^{1}$ (D) \\ 1 Microbiology, DIMES, Alma Mater Studiorum, University of Bologna, 40138 Bologna, Italy; \\ claudio.foschi2@unibo.it (C.F.); sara.morselli6@unibo.it (S.M.); antonella.marangoni@unibo.it (A.M.) \\ 2 Department of Pharmacy and Biotechnology, Alma Mater Studiorum, University of Bologna, \\ 40127 Bologna, Italy; barbara.giordani4@unibo.it (B.G.); barbara.luppi@unibo.it (B.L.); b.vitali@unibo.it (B.V.) \\ * Correspondence: carola.parolin@unibo.it; Tel.: +39-051-2088750
}

check for

updates

Citation: Foschi, C.; Parolin, C.; Giordani, B.; Morselli, S.; Luppi, B.; Vitali, B.; Marangoni, A. Lactobacillus crispatus BC1 Biosurfactant Counteracts the Infectivity of Chlamydia trachomatis Elementary Bodies. Microorganisms 2021, 9, 975. https://doi.org/10.3390/

microorganisms 9050975

Academic Editor: Piotr B. Heczko

Received: 15 March 2021

Accepted: 27 April 2021

Published: 30 April 2021

Publisher's Note: MDPI stays neutral with regard to jurisdictional claims in published maps and institutional affiliations.

Copyright: (c) 2021 by the authors. Licensee MDPI, Basel, Switzerland. This article is an open access article distributed under the terms and conditions of the Creative Commons Attribution (CC BY) license (https:// creativecommons.org/licenses/by/ $4.0 /)$.

\begin{abstract}
Lactobacilli-derived biosurfactants (BS) have shown promising effects as antimicrobial molecules. Since Lactobacillus crispatus plays a crucial role in maintaining vaginal eubiosis, BS from this species could represent novel therapeutic agents to counteract sexually transmitted pathogens, such as Chlamydia trachomatis (CT). The aim of the present study was to assess the inhibitory effects of a BS produced by the vaginal strain L. crispatus BC1 on the infectivity of CT elementary bodies (EBs). For concentrations ranging between 1 and $0.5 \mathrm{mg} / \mathrm{mL}$ at $60-\mathrm{min}$ contact time, L. crispatus BC1 BS displayed a highly significant anti-CT activity, with about $50 \%$ reduction of EB infectivity towards HeLa cells. To identify the components responsible for chlamydial inhibition, a panel of selected fatty acids, including those present in BS lipopeptidic structure, was tested against CT EBs. Pentadecanoic acid, myristic acid, $\beta$-hydroxy-myristic acid, and $\beta$-hydroxy-palmitic acid were able to significantly reduce EBs infectivity up to $5-0.5 \mu \mathrm{g} / \mathrm{mL}$, concentrations that resulted to be non-toxic for HeLa cells. These data can contribute to the understanding of the biological role of lactobacilli in the vaginal niche, as well as to promote the application of their produced BS as an innovative and antibiotic-sparing anti-chlamydial strategy.
\end{abstract}

Keywords: lactobacilli; Lactobacillus crispatus; biosurfactants; Chlamydia trachomatis; fatty acids

\section{Introduction}

The obligate intracellular bacterium Chlamydia trachomatis (CT) is the agent of the most common bacterial sexually transmitted infection (STI) worldwide [1]. In women, a high proportion of urogenital chlamydial infections are asymptomatic and thereby left untreated, favoring the occurrence of several complications and sequelae, including pelvic inflammatory disease, infertility, and ectopic pregnancy $[2,3]$.

A vaginal microbiota dominated by lactobacilli is crucial for the prevention of several STIs, including Chlamydia [4-8]. The protective role of lactobacilli against urogenital pathogens is exerted through various mechanisms, such as the production of antimicrobial compounds (e.g., lactic acid, bacteriocins, hydrogen peroxide, biosurfactants), co-aggregation, competitive exclusion, and immunomodulation [9-11].

Until now, only a few studies have focused on the in vitro interaction between lactobacilli and CT, elucidating some of the antibacterial mechanisms displayed by lactobacilli [6,12-14]. Previous works demonstrated that lactate production and acidification of the environment are critical for the anti-chlamydial activity, in addition to the consumption of the carbonate source represented by glucose [6,12]. Moreover, lactobacilli can interfere with CT infection by altering lipid composition and $\alpha 5$ integrin subunit exposure in epithelial cells' plasma membrane [14]. To the best of our knowledge, no studies have yet investigated the anti-chlamydial activity of biosurfactants derived from lactobacilli. 
Biosurfactants (BS) are amphiphilic compounds produced by microorganisms, anchored on the surface or secreted to the outside, with useful physicochemical and biological properties $[15,16]$. Among all their critical functions and applications, BS and particularly lactobacilli-derived BS have shown promising effects as antimicrobial molecules, both against bacteria and fungi [17-20]. Since Lactobacillus crispatus plays a crucial role in maintaining vaginal eubiosis [21], BS from this species could represent novel therapeutic agents to counteract $\mathrm{CT}$ infection. In this context, the aim of the present study was to assess the inhibitory effects of a BS produced by the vaginal strain L. crispatus BC1 on the infectivity of $\mathrm{CT}$ elementary bodies (EBs), as well as to identify the BS structural components related to the antibacterial activity. Our data can contribute to the understanding of the biological role of lactobacilli in the vaginal niche, as well as to promote the application of their isolated components against sexually transmitted pathogens.

\section{Materials and Methods}

\subsection{C. trachomatis Strain and Cell Culture}

C. trachomatis strain GO/86, serotype D, was used for the experiments [6,22]. This strain was originally isolated from a patient with non-gonococcal urethritis and belongs to the collection of the Microbiology Laboratory of Sant'Orsola-Malpighi Hospital in Bologna (Italy).

HeLa cells (ATCC CCL-2), a cell line originated from a human cervix carcinoma, were grown to confluent monolayers in $5 \% \mathrm{CO}_{2}$ at $37^{\circ} \mathrm{C}$. CT was propagated in HeLa cells, cultured in Dulbecco's minimal essential medium (DMEM) (EuroClone, Pero, Italy), supplemented with $10 \%$ fetal bovine serum, $1 \%$ L-glutamine $200 \mathrm{mM}$, and antibiotics (vancomycin $10 \mathrm{mg} / \mathrm{L}$, gentamicin $10 \mathrm{mg} / \mathrm{L}$, and amphotericin B $0.3 \mathrm{mg} / \mathrm{L}$ ). For the preparation of EBs, confluent HeLa cells were infected with CT in a DMEM medium supplemented with cycloheximide $1 \mu \mathrm{g} / \mathrm{mL}$, centrifuged at $640 \times \mathrm{g}$ for $2 \mathrm{~h}$ to facilitate cell penetration, then incubated at $37^{\circ} \mathrm{C}$ with $5 \% \mathrm{CO}_{2}$ for $48 \mathrm{~h}$ [13]. HeLa cells were then detached and fragmented by sonication, by using a Bandelin sonicator at minimum power. Samples were centrifuged at $500 \times g$ for $10 \mathrm{~min}$ at $4{ }^{\circ} \mathrm{C}$, and supernatants, which contain EBs, were further centrifuged at $40,000 \times g$ at $4{ }^{\circ} \mathrm{C}$ for $1 \mathrm{~h}$. The resulting pellets were re-suspended in sucrose-phosphate-glutamate (SPG) $0.2 \mathrm{M}$, divided into small aliquots, and stored at $-80^{\circ} \mathrm{C}$.

The infectious titre (inclusion-forming units (IFU)/mL) was assessed by immunofluorescence assay. Briefly, HeLa cells were infected with tenfold serial dilutions of bacterial stock, centrifuged at $640 \times g$ for $2 \mathrm{~h}$, and incubated for $48 \mathrm{~h}$ at $37^{\circ} \mathrm{C}$. Afterwards, cells were fixed with methanol, and stained with a monoclonal antibody against the chlamydial membrane lipopolysaccharide antigen conjugated with fluorescein (Meridian, Cincinnati, $\mathrm{OH}, \mathrm{USA}$ ), as previously reported [22]. Slides were observed under epi-fluorescence microscope (Eclipse E600, Nikon, Japan) equipped with a super-high-pressure mercury lamp and Plan Fluor DLL $20 \times, 40 \times, 100 \times$ lenses. The total number of CT IFU was enumerated by counting all microscope fields.

\subsection{Isolation of $B S$ from $L$. crispatus $B C 1$}

L. crispatus $\mathrm{BC} 1$ was isolated from the vaginal swab of a healthy premenopausal woman [23]. BC1 strain was cultured in de Man, Rogosa and Sharpe (MRS) broth (Beckton, Dickinson and Co., Milan, Italy) supplemented with $0.05 \% \mathrm{~L}$-cysteine, at $37^{\circ} \mathrm{C}$ for $24 \mathrm{~h}$ in anaerobic jars containing GasPak EZ (Beckton, Dickinson and Co.).

The cell-bound BS was isolated from L. crispatus BC1 as previously reported $[19,24]$. Briefly, $\mathrm{BC} 1$ strain was cultured in $1 \mathrm{~L}$ of MRS broth for $48 \mathrm{~h}$ in anaerobic conditions. The cell pellet was harvested by centrifugation $(10,000 \times g, 15 \mathrm{~min})$, washed twice in sterile distilled water, resuspended in $240 \mathrm{~mL}$ of sterile PBS, and gently stirred at room temperature for $2 \mathrm{~h}$ to release the cell-bound BS. The suspension was centrifuged, and the supernatant filtered through a $0.22 \mu \mathrm{m}$ pore size filter (PES $0.22 \mu \mathrm{m}$ syringe filters, VWR International, Milan, Italy). Cell-free supernatant was subjected to dialysis against demineralized water 
in a Cellu-Sep@ $\odot$ membrane (molecular weight cut-off 6000-8000 Da; Spectra/Por 2 dialysis membrane, Spectrum Laboratories Inc., Rancho Dominguez, CA, USA) for $24 \mathrm{~h}$ at room temperature, and freeze-dried at $0.01 \mathrm{~atm}$ and $-45^{\circ} \mathrm{C}$ (Christ Freeze Dryer ALPHA 1-2, Milan, Italy). BS produced by L. crispatus $\mathrm{BC} 1$ possesses a lipopeptidic structure as defined by De Gregorio et al. 2020 [25].

\subsection{Anti-Chlamydial Activity of BS}

The antimicrobial activity of BS was tested against $C$. trachomatis EBs by in vitro inhibition assay. Lyophilized BS was solubilized in phosphate buffer saline (PBS) at a concentration of $2 \mathrm{mg} / \mathrm{mL}$ and serially diluted. The different concentrations of BS (ranging from $2 \mathrm{mg} / \mathrm{mL}$ to $0.12 \mathrm{mg} / \mathrm{mL}$ ) were mixed with $5 \times 10^{3}, 5 \times 10^{4}$, and $5 \times 10^{5} \mathrm{CT}$ EBs (100 $\mu \mathrm{L}$ of stock solutions of $5 \times 10^{4}, 5 \times 10^{5}$, and $5 \times 10^{6} \mathrm{IFU} / \mathrm{mL}$, diluted in saline) in a final volume of $200 \mu \mathrm{L}$. The same amount of EBs mixed with PBS (in absence of BS) was used as control. Mixes were incubated for 7 and $60 \mathrm{~min}$ at $37^{\circ} \mathrm{C}$ in $5 \% \mathrm{CO}_{2}$ atmosphere. Afterwards, they were inoculated into HeLa cells, grown in DMEM medium to confluence in individual tubes containing sterile coverslips, and centrifuged at $640 \times g$ for $1 \mathrm{~h}$ to facilitate chlamydial cell penetration. At the end of the centrifugation, culture medium was replaced with fresh DMEM, and HeLa cells were incubated at $37{ }^{\circ} \mathrm{C}$ with $5 \% \mathrm{CO}_{2}$ for $48 \mathrm{~h}$. C. trachomatis infection was evaluated by counting chlamydial IFU by direct immunofluorescence as described above. The number of IFU was counted in 30 randomly chosen $200 \times$ microscopic fields. The $\mathrm{pH}$ values of the final solutions (BS added to CT EBs) were checked by a $\mathrm{pH}$ meter, after appropriate calibration.

\subsection{Anti-Chlamydial Effect of Selected Fatty Acids}

The anti-chlamydial effect of selected fatty acids was assessed following the same protocol described for BS. In particular, tridecanoic acid, myristic acid, $\beta$-hydroxy-myristic acid, pentadecanoic acid, palmitic acid, and $\beta$-hydroxy-palmitic acid were purchased from CliniSciences (Rome, Italy), solubilized in DMSO, and serially diluted in PBS. The $\mathrm{pH}$ values of the final solutions (fatty acid solutions added to CT EBs) were measured by a $\mathrm{pH}$ meter. Fatty acids were tested against $\mathrm{CT}\left(5 \times 10^{3} \mathrm{EBs}\right)$ at final concentrations ranging from 50 to $0.05 \mu \mathrm{g} / \mathrm{mL}$, after $60 \mathrm{~min}$ of incubation with EBs.

\subsection{Cytotoxicity of Fatty Acids}

The cytotoxic effect of fatty acids on HeLa cells was assessed by 3-(45-dimethylthiazol2-yl)-2,5-diphenyltetrazol (MTT) assay, as previously reported [25]. In particular, tridecanoic acid, myristic acid, $\beta$-hydroxy-myristic acid, pentadecanoic acid, palmitic acid, and $\beta$-hydroxy-palmitic acid were solubilized in DMSO $(10 \mathrm{mg} / \mathrm{mL})$ and diluted in DMEM complete medium immediately before cell treatment. HeLa cells were grown in 96-well plates to $70 \%$ confluence at $37{ }^{\circ} \mathrm{C}$ with $5 \% \mathrm{CO}_{2}$, then treated with fatty acids at different concentrations, ranging from 50 to $0.05 \mu \mathrm{g} / \mathrm{mL}$. The solubilizing agent (DMSO) at same dilutions was also tested and used as control, as well as untreated cells. After $24 \mathrm{~h}$ of treatment, medium was replaced by $110 \mu \mathrm{L}$ of MTT solution in DMEM (final concentration $0.5 \mathrm{mg} / \mathrm{mL}$ ) and the plates were further incubated for $4 \mathrm{~h}$ at $37^{\circ} \mathrm{C}, 5 \% \mathrm{CO}_{2}$. The formazan crystals that formed were dissolved by the addition of isopropanol and quantified by optical density at $570 \mathrm{~nm}$ using an EnSpire Multimode Plate Reader (PerkinElmer Inc., Waltham, MA, USA).

\subsection{Statistical Analysis}

All statistical analyses were performed by using GraphPad Prism software (GraphPad Prism version 5.02 for Windows, GraphPad Software, San Diego, CA, USA, www.graphpad. com (accessed on 27 April 2021)). A one-way analysis of variance (ANOVA) test followed by Dunnett's multiple comparison test was used to assess the anti-CT and cytotoxic effect of BS and selected fatty acids. Results were expressed as mean \pm standard error of the mean (SEM). Statistical significance was determined at ${ }^{*} p<0.05$, ${ }^{* *} p<0.01$, and ${ }^{* * *} p<0.0001$. 


\section{Results}

\subsection{Effect of L. crispatus BS against CT EBS}

BS isolated from $L$. crispatus $\mathrm{BC} 1$ displayed a significant killing activity against CT EBs $\left(5 \times 10^{3} \mathrm{EBs}\right)$ for concentrations of 1 and $0.5 \mathrm{mg} / \mathrm{mL}$ after $60 \mathrm{~min}$ of incubation, as shown in Figure 1. Raw quantitative data on chlamydial IFU number, as well as images of HeLa monolayers infected with CT in the different experimental conditions, are shown in Supplementary Figure S1 and Table S1. Higher BS concentrations have not been tested against $\mathrm{CT}$, considering the cytotoxic effect of BS on HeLa cells already demonstrated by De Gregorio et al. [25]. No inhibitory effect after $7 \mathrm{~min}$ of contact was noticed (data not shown). As expected, BS solutions maintained $\mathrm{pH}$ values of 7.0, thus excluding a killing effect due to an acidic milieu.

When higher concentrations of CT EBs were used (i.e., $5 \times 10^{4}$ and $5 \times 10^{5} \mathrm{EBs}$ ), L. crispatus BC1-derived BS lost its anti-chlamydial activity (data not shown).

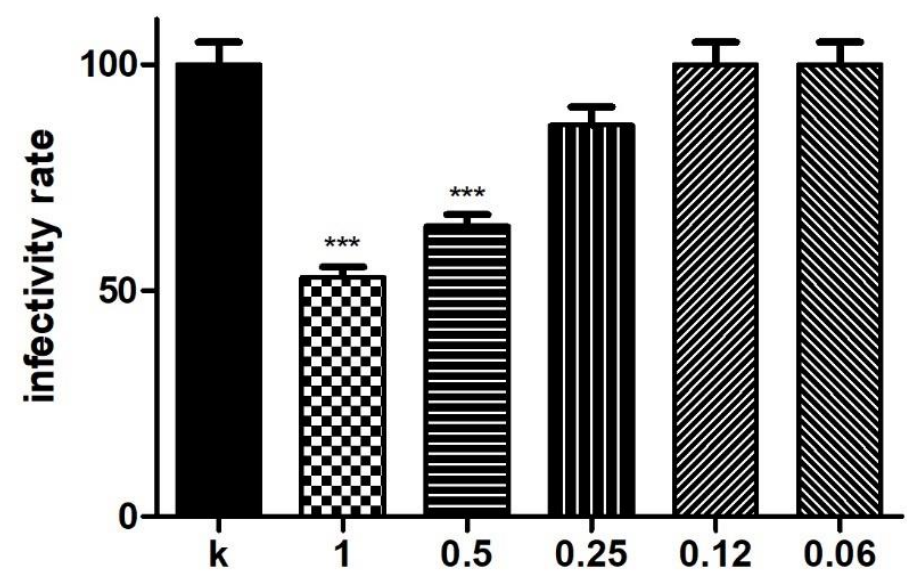

Figure 1. Anti-chlamydial effect of BS derived from L. crispatus BC1. Experiments were performed with different concentrations of BS diluted in PBS (final concentrations ranging from 1 to $0.06 \mathrm{mg} / \mathrm{mL}$ ) added to $5 \times 10^{3}$ EBs at 60-min time point. Chlamydial infectivity was evaluated as IFU/field and expressed as \% of control (K) $\left(5 \times 10^{3}\right.$ EBs incubated in PBS), taken as $100 \%$. Bars represent mean values, error bars represent SEM. ${ }^{* * *} p<0.0001$.

\subsection{Anti-Chlamydial Effect of Fatty Acids Contained in L. crispatus BC1-Derived BS}

As previously described, the main fatty acids found in the BS were $\beta$-hydroxytridecanoic acid (3-OH-C13), $\beta$-hydroxy-tetradecanoic acid (3-OHC14; $\beta$-hydroxy-myristic acid), $\beta$-hydroxy-pentadecanoic acid (3-OH-C15), and $\beta$-hydroxy-hexadecanoic acid (3$\mathrm{OH}-\mathrm{C} 16 ; \beta$-hydroxy-palmitic acid) [25]. In line with these findings, to unravel the BS components associated with the antibacterial activity, we evaluated the anti-chlamydial effect of $\beta$-hydroxy-myristic acid and $\beta$-hydroxy-palmitic acid. Unfortunately, we were not able to test $\beta$-hydroxy-pentadecanoic acid and $\beta$-hydroxy-tridecanoic acids due to supply difficulties. In addition, we tested all the non-hydroxylated forms of the acids present in the lipopeptide structure (i.e., myristic acid, palmitic acid, tridecanoic acid, and pentadecanoic acid), in order to evaluate the effect of the beta substitution on biological activity (Figure 2). All the acids, except tridecanoic acid, displayed a high killing activity against CT up to concentrations of $5-0.5 \mu \mathrm{g} / \mathrm{mL}$, with a dose-response effect. The best antimicrobial activity was exhibited by $\beta$-hydroxy-myristic and myristic acids, which were almost able to abolish $\mathrm{CT}$ viability at the highest concentrations tested. Interestingly, $\beta$-hydroxy-palmitic acid showed a much higher anti-chlamydial activity (50-60\% more) compared to its non-hydroxylated form. The mixtures of CT EBs added with fatty acid solutions had $\mathrm{pH}$ values ranging between 7.4 and 7.5. 

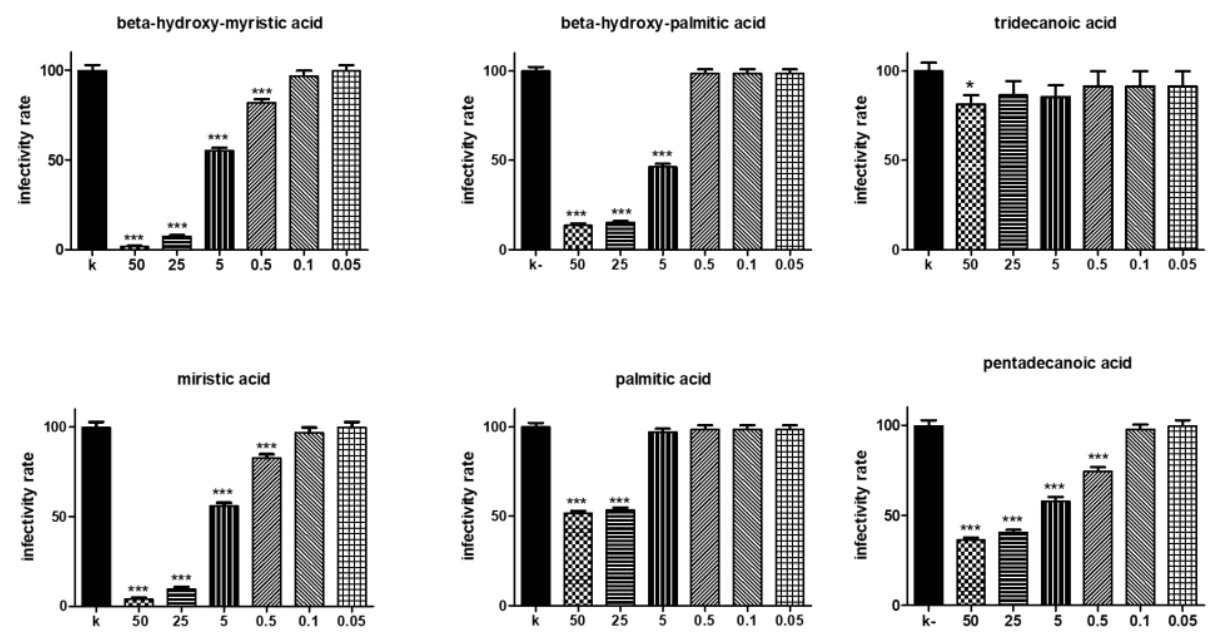

Figure 2. Anti-chlamydial effect of selected fatty acids. Experiments were performed with different concentrations of fatty acids (final concentrations ranging from 50 to $0.05 \mu \mathrm{g} / \mathrm{mL}$ ) added to $5 \times 10^{3}$ EBs at 60-min time point. Chlamydial infectivity was evaluated as IFU/field and expressed as $\%$ of control $(\mathrm{K})\left(5 \times 10^{3} \mathrm{EBs}\right.$ incubated in PBS), taken as $100 \%$. Bars represent mean values, error bars represent SEM. ${ }^{* * *} p<0.0001$.

\subsection{Cytotoxicity of Fatty Acids}

The same fatty acids tested on CT infectivity were also analyzed for their toxicity on cervical epithelial cells by MTT assay (Figure 3). $\beta$-hydroxy-myristic acid, miristic acid, tridecanoic acid, and pentadecanoic acid did not affect cell viability at concentrations up to $50 \mu \mathrm{g} / \mathrm{mL}$. In contrast, palmitic acid and the corresponding hydroxylated form significantly decreased HeLa cells' viability at the highest tested doses. In particular, $50 \mu \mathrm{g} / \mathrm{mL} \beta$-hydroxy-palmitic acid reduced cell viability by $59.41 \%$, whereas the same dose of palmitic acid reduced cell viability by $23.44 \%$. $\beta$-hydroxy-palmitic acid induced a significant decrease of cell viability $(48.71 \%)$ also when administered at $25 \mu \mathrm{g} / \mathrm{mL}$. Vehicle molecule (DMSO) did not show any cytotoxic effect at the tested doses (data not shown).

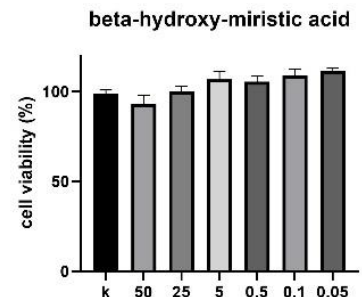

miristic acid

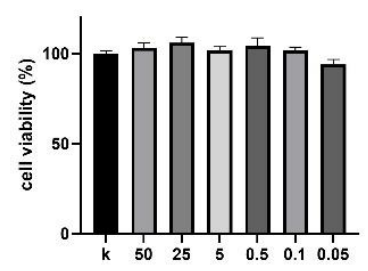

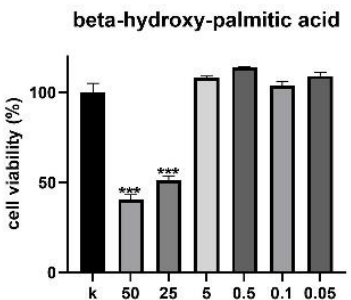

palmitic acid

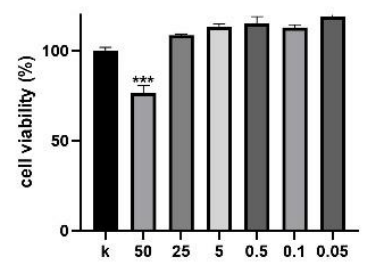

tridecanoid acid

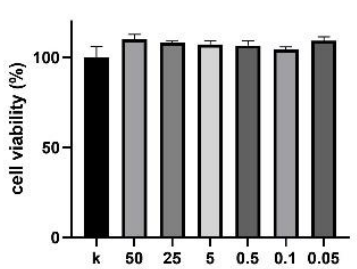

pentadecanoid acid

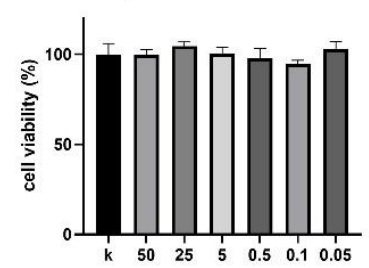

Figure 3. Cytotoxic effect of selected fatty acids on HeLa cells. MTT assay of HeLa cells treated with different concentrations of fatty acids (ranging from 50 to $0.05 \mu \mathrm{g} / \mathrm{mL}$ ) for $24 \mathrm{~h}$. Cell viability was expressed as \% of control (K) (untreated cells), taken as 100\%. Bars represent mean values, error bars represent SEM. ${ }^{* * *} p<0.0001$.

\section{Discussion}

To the best of our knowledge, this is the first report assessing the activity of a Lactobacillus-derived BS against $C$. trachomatis. In particular, we investigated the anti-chlamydial 
effect of a BS isolated from a vaginal L. crispatus strain (L. crispatus BC1), by means of in vitro inhibition assays against CT EBs. For concentrations ranging between 1 and $0.5 \mathrm{mg} / \mathrm{mL}$, L. crispatus BC1 BS displayed a highly significant anti-CT activity, with a $50 \%$ reduction of EB infectivity towards HeLa cells, when $5 \times 10^{3}$ EBs were used. For higher chlamydial concentrations ( $5 \times 10^{4}$ and $\left.5 \times 10^{5} \mathrm{EBs}\right)$, L. crispatus BC1-derived BS lost its anti-chlamydial activity. In this context, it should be underlined that, usually, genital CT infections are characterized by low infectious and low bacterial loads [26,27]. Thus, the activity of lactobacilli BS against $5 \times 10^{3} \mathrm{CT}$ EBs better mimics the physiological and natural course of $\mathrm{CT}$ genital infections.

In previous works, we highlighted the antimicrobial activity of L. crispatus BC1 fractions (i.e., lactobacilli cells and cell-free supernatant) against several urogenital and STI pathogens, such as Candida spp., C. trachomatis, Neisseria gonorrhoeae, and Streptococcus agalactiae $[6-8,23,28]$. Moreover, L. crispatus BC1-derived BS was recently indicated as a promising safe agent able to interfere with important Candida virulence factors, i.e., adhesion to cervicovaginal cells and biofilm formation $[20,25]$. In this context, our data added knowledge on the functions of lactobacilli-isolated BS, shedding light on new antimicrobial mechanisms and opening the way to the use of BS as an innovative and antibiotic-sparing anti-chlamydial strategy.

Cell-bound $\mathrm{BS}$ recovered from L. crispatus $\mathrm{BC} 1$ were previously characterised from the chemical point of view and turned out to have a lipopeptidic nature [25]. To identify the BS components responsible for the inhibition of Chlamydia infectivity, a panel of selected fatty acids, including those present in L. crispatus BC1 BS structure, was tested against CT EBs. Such fatty acids were also assessed for safety on HeLa cells that represent the in vitro target of CT EBs and an appropriate cellular model in the perspective of using BS as a CT-infection antagonist.

Several long-chain fatty acids exerted a prominent killing activity against CT EBs, with a dose-dependent profile. In particular, $\beta$-hydroxy-myristic acid and $\beta$-hydroxypalmitic acid, retrieved in L. crispatus BC1 BS structure, were able to significantly reduce EBs infectivity up to low concentrations. Besides this, anti-CT activity varied with the length of the fatty acid chain, with tridecanoic acid the less active and myristic acid the most active.

The effects of short chain fatty acids (SCFAs) produced by lactobacilli and other vaginal microbiota inhabitants (e.g., lactic acid, acetate, propionate, butyrate, and succinate) have been largely investigated, with the comprehension of their different antimicrobial and immune modulatory activities $[29,30]$.

Conversely, the functionality of medium- and long-chain fatty acids on the microbial cells has been only partially explored. Medium- and long-chain free fatty acids have been found to have a broad spectrum of microbicidal in vitro activity against various bacteria, including some pathogens responsible for urogenital and sexually transmitted infections [31-36]. However, their antimicrobial effects varied greatly depending not only on fatty acid concentration and structure (length of fatty acid chain and type of derivatives), but also on the microorganism and bacterial species tested. In this context, Bergsson et al. showed that various fatty acids are able to inactivate $C$. trachomatis infectivity, by means of a direct disruption of EBs membranes [31]. For short contact times (i.e., 10 min of incubation), lauric acid, capric acid, and monocaprin acid cause a greater than 10,000-fold reduction in CT infectivity titre, whereas myristic acid, palmitoleic acid, and oleic acid have negligible effects on CT.

Here, we demonstrated that, after $60 \mathrm{~min}$ of incubation, myristic acid and its hydroxylated form are highly active against CT EBs, thus suggesting that contact time is a significant parameter to assess the antimicrobial effect of fatty acids. In addition, we proved, for the first time, the anti-chlamydial activity of pentadecanoic acid and $\beta$-hydroxy-palmitic acid. In our experience, palmitic acid exerted much less activity against CT EBs compared to its hydroxylated form. Interestingly, it has been shown that exogenous palmitic acid is incorporated into chlamydial synthesized phospholipids, thus potentially explaining the lower 
inhibition activity displayed by this acid compared to its hydroxylated derivative [37]. Overall, our data strengthen the idea that selected fatty acids may be useful as microbicidal compounds for the prevention and treatment of C. trachomatis infections [38].

L. crispatus BC1 BS was proven to be safe at doses capable of reducing CT infection [25]. In addition, among tested fatty acids, only $\beta$-hydroxy-palmitic acid and the respective non-hydroxylated form affected HeLa cells' viability, suggesting a specific or preferential interaction of tetradecanoic fatty acid with epithelial cells. Although it is well recognized the induction of mitochondrial damage and apoptosis by free saturated fatty acids in multiple cell types, including hepatocytes and breast cancer cell lines [39,40], little is known on the contribution of fatty acid chain length on lipotoxicity. Indeed, several studies reported the use of palmitic acid or palmitate as the most representative saturated fatty acid, without analysing the effects of longer or shorter fatty acids [41,42]. Our results suggested a key impact of fatty acids chain lengths and hydroxylation on lipotoxicity.

In conclusion, this study elucidates the mechanisms underlying the protective role of vaginal microbiota against $C$. trachomatis, identifying BS and their acid components as important factors responsible for the inhibitory activity of lactobacilli. These results open the perspective of using both BS and the active fatty acids as new therapeutic agents as an alternative to traditional antibiotics that present problems of toxicity and bacterial resistance.

Further studies are needed to exactly quantify the amount of the various fatty acids in L. crispatus $\mathrm{BC} 1 \mathrm{BS}$, as well as to understand the mechanisms of action by which fatty acids counteract EBs infectivity. In this context, ex vivo and in vivo models, such as polarized human fallopian tube epithelial cells and animal models [43,44], could be employed to better represent the complexity of $\mathrm{CT}$ infection and improve translational relevance.

Supplementary Materials: The following are available online at https:/ / www.mdpi.com/article/10 .3390 / microorganisms9050975/s1, Figure S1: Images of HeLa monolayers infected with C. trachomatis in the different experimental conditions, Table S1: Raw data of C. trachomatis inclusion-forming units (IFU) number counted for each experimental condition.

Author Contributions: Conceptualization, C.F., B.V. and A.M.; methodology, C.F., C.P., B.G., S.M., B.L.; investigation, C.F., C.P., B.G., S.M.; data curation, C.F., C.P., B.G.; writing-original draft preparation, C.F., C.P., B.G., B.V., A.M.; writing-review and editing, S.M., B.L.; visualization, C.F., C.P.; supervision, B.V., A.M., B.L.; funding acquisition, B.V., A.M. All authors have read and agreed to the published version of the manuscript.

Funding: This research received no external funding.

Institutional Review Board Statement: Not applicable.

Informed Consent Statement: Not applicable.

Data Availability Statement: Data is contained within the article and Supplementary Material.

Conflicts of Interest: The authors declare no conflict of interest.

\section{References}

1. Senior, K. Chlamydia: A much underestimated STI. Lancet Infect. Dis. 2012, 12, 517-518. [CrossRef]

2. Haggerty, C.L.; Gottlieb, S.L.; Taylor, B.D.; Low, N.; Xu, F.; Ness, R.B. Risk of sequelae after Chlamydia trachomatis genital infection in women. J. Infect. Dis. 2010, 201, S134-S155. [CrossRef] [PubMed]

3. Price, M.J.; Ades, A.E.; De Angelis, D.; Welton, N.J.; Macleod, J.; Soldan, K.; Simms, I.; Turner, K.; Horner, P.J. Risk of pelvic inflammatory disease following Chlamydia trachomatis infection: Analysis of prospective studies with a multistate model. Am. J. Epidemiol. 2013, 178, 484-492. [CrossRef] [PubMed]

4. Edwards, V.L.; Smith, S.B.; McComb, E.J.; Tamarelle, J.; Ma, B.; Humphrys, M.S.; Gajer, P.; Gwilliam, K.; Schaefer, A.M.; Lai, S.K.; et al. The cervicovaginal microbiota-host interaction modulates Chlamydia trachomatis infection. mBio 2019, 10, e01548-19. [CrossRef] [PubMed]

5. Gupta, S.; Kakkar, V.; Bhushan, I. Crosstalk between Vaginal Microbiome and Female Health: A review. Microb. Pathog. 2019, 136, 103696. [CrossRef]

6. Nardini, P.; Ñahui Palomino, R.A.; Parolin, C.; Laghi, L.; Foschi, C.; Cevenini, R.; Vitali, B.; Marangoni, A. Lactobacillus crispatus inhibits the infectivity of Chlamydia trachomatis elementary bodies, in vitro study. Sci. Rep. 2016, 6, 29024. [CrossRef] [PubMed] 
7. Foschi, C.; Salvo, M.; Cevenini, R.; Parolin, C.; Vitali, B.; Marangoni, A. Vaginal lactobacilli reduce Neisseria gonorrhoeae viability through multiple strategies: An in vitro study. Front. Cell. Infect. Microbiol. 2017, 7, 502. [CrossRef] [PubMed]

8. Nahui Palomino, R.A.; Zicari, S.; Vanpouille, C.; Vitali, B.; Margolis, L. Vaginal Lactobacillus inhibits HIV-1 replication in human tissues ex vivo. Front. Microbiol. 2017, 8, 906. [CrossRef] [PubMed]

9. Aroutcheva, A.; Gariti, D.; Simon, M.; Shott, S.; Faro, J.; Simoes, J.A.; Gurguis, A.; Faro, S. Defense factors of vaginal lactobacilli. Am. J. Obstet. Gynecol. 2001, 185, 375-379. [CrossRef]

10. Kaewsrichan, J.; Peeyananjarassri, K.; Kongprasertkit, J. Selection and identification of anaerobic lactobacilli producing inhibitory compounds against vaginal pathogens. FEMS Immunol. Med. Microbiol. 2006, 48, 75-83. [CrossRef] [PubMed]

11. Borges, S.; Silva, J.; Teixeira, P. The role of lactobacilli and probiotics in maintaining vaginal health. Arch. Gynecol. Obstet. 2014, 289, 479-489. [CrossRef] [PubMed]

12. Gong, Z.; Luna, Y.; Yu, P.; Fan, H. Lactobacilli inactivate Chlamydia trachomatis through lactic acid but not $\mathrm{H}_{2} \mathrm{O}_{2}$. PLoS ONE 2014, 9, e107758. [CrossRef] [PubMed]

13. Mastromarino, P.; Di Pietro, M.; Schiavoni, G.M.; Nardis, C.; Gentile, M.; Sessa, R. Effects of vaginal lactobacilli in Chlamydia trachomatis infection. Int. J. Med. Microbiol. 2014, 304, 654-661. [CrossRef] [PubMed]

14. Parolin, C.; Frisco, G.; Foschi, C.; Giordani, B.; Salvo, M.; Vitali, B.; Marangoni, A.; Calonghi, N. Lactobacillus crispatus BC5 interferes with Chlamydia trachomatis infectivity through integrin modulation in cervical cells. Front. Microbiol. 2018, 9, 2630. [CrossRef] [PubMed]

15. Gudiña, E.; Rangarajan, V.; Sen, R.; Rodrigues, L. Potential therapeutic applications of biosurfactants. Trends Pharmacol. Sci. 2013, 34, 667-675. [CrossRef] [PubMed]

16. Ruksana, J.; Andrew, M.B.; Marina, T.; Paschalis, A. Biosurfactants, natural alternatives to synthetic surfactants: Physicochemical properties and applications. Adv. Colloid Interface Sci. 2020, 275, 2061. [CrossRef]

17. Morais, I.M.C.; Cordeiro, A.L.; Teixeira, G.S.; Domingues, V.S.; Nardi, R.M.D.; Monteiro, A.S.; Alves, R.J.; Siqueira, E.P.; Santos, V.L. Biological and physicochemical properties of biosurfactants produced by Lactobacillus jensenii P6A and Lactobacillus gasseri P65. Microb. Cell Fact. 2017, 16, 155. [CrossRef]

18. Giordani, B.; Costantini, P.E.; Fedi, S.; Cappelletti, M.; Abruzzo, A.; Parolin, C.; Foschi, C.; Frisco, G.; Calonghi, N.; Cerchiara, T.; et al. Liposomes containing biosurfactants isolated from Lactobacillus gasseri exert antibiofilm activity against methicillin resistant Staphylococcus aureus strains. Eur. J. Pharm. Biopharm. 2019, 139, 246-252. [CrossRef]

19. Satpute, S.K.; Kulkarni, G.R.; Banpurkar, A.G.; Banat, I.M.; Mone, N.S.; Patil, R.H.; Cameotra, S.S. Biosurfactant/s from Lactobacilli species: Properties, challenges and potential biomedical applications. J. Basic Microbiol. 2016, 56, 1140-1158. [CrossRef]

20. Abruzzo, A.; Giordani, B.; Parolin, C.; De Gregorio, P.R.; Foschi, C.; Cerchiara, T.; Bigucci, F.; Vitali, B.; Luppi, B. Lactobacillus crispatus BC1 biosurfactant delivered by hyalurosomes: An advanced strategy to counteract Candida biofilm. Antibiotics 2021, 10, 33. [CrossRef]

21. Ceccarani, C.; Foschi, C.; Parolin, C.; D’Antuono, A.; Gaspari, V.; Consolandi, C.; Laghi, L.; Camboni, T.; Vitali, B.; Severgnini, M.; et al. Diversity of vaginal microbiome and metabolome during genital infections. Sci. Rep. 2019, 9, 14095. [CrossRef]

22. Marangoni, A.; Fiorino, E.; Gilardi, F.; Aldini, R.; Scotti, E.; Nardini, P.; Foschi, C.; Donati, M.; Montagnani, M.; Cevenini, M.; et al. Chlamydia pneumoniae acute liver infection affects hepatic cholesterol and triglyceride metabolism in mice. Atherosclerosis 2015, 241, 471-479. [CrossRef]

23. Parolin, C.; Marangoni, A.; Laghi, L.; Foschi, C.; Nahui Palomino, R.A.; Calonghi, N.; Cevenini, R.; Vitali, B. Isolation of vaginal lactobacilli and characterization of anti-Candida activity. PLoS ONE 2015, 10, e0131220. [CrossRef]

24. Sharma, D.; Saharan, B.S. Functional characterization of biomedical potential of biosurfactant produced by Lactobacillus helveticus. Biotechnol. Rep. (Amst) 2016, 11, 27-35. [CrossRef] [PubMed]

25. De Gregorio, P.R.; Parolin, C.; Abruzzo, A.; Luppi, B.; Protti, M.; Mercolini, L.; Silva, J.A.; Giordani, B.; Marangoni, A.; NaderMacías, M.E.F.; et al. Biosurfactant from vaginal Lactobacillus crispatus $\mathrm{BC} 1$ as a promising agent to interfere with Candida adhesion. Microb. Cell Fact. 2020, 19, 133. [CrossRef] [PubMed]

26. Rank, R.G.; Bowlin, A.K.; Reed, R.L.; Darville, T. Characterization of chlamydial genital infection resulting from sexual transmission from male to female guinea pigs and determination of infectious dose. Infect. Immun. 2003, 71, 6148-6154. [CrossRef] [PubMed]

27. Dukers-Muijrers, N.H.; Speksnijder, A.G.; Morré, S.A.; Wolffs, P.F.; van der Sande, M.A.; Brink, A.A.; van den Broek, I.V.; Werner, M.I.; Hoebe, C.J. Detection of anorectal and cervicovaginal Chlamydia trachomatis infections following azithromycin treatment: Prospective cohort study with multiple time-sequential measures of rRNA, DNA, quantitative load and symptoms. PLoS ONE 2013, 8, e81236. [CrossRef]

28. Marziali, G.; Foschi, C.; Parolin, C.; Vitali, B.; Marangoni, A. In-Vitro effect of vaginal lactobacilli against group B Streptococcus. Microb. Pathog. 2019, 136, 103692. [CrossRef]

29. Aldunate, M.; Srbinovski, D.; Hearps, A.C.; Latham, C.F.; Ramsland, P.A.; Gugasyan, R.; Cone, R.A.; Tachedjian, G. Antimicrobial and immune modulatory effects of lactic acid and short chain fatty acids produced by vaginal microbiota associated with eubiosis and bacterial vaginosis. Front. Physiol. 2015, 6, 164. [CrossRef] [PubMed]

30. Delgado-Diaz, D.J.; Tyssen, D.; Hayward, J.A.; Gugasyan, R.; Hearps, A.C.; Tachedjian, G. Distinct immune responses elicited from cervicovaginal epithelial cells by lactic acid and short chain fatty acids associated with optimal and non-optimal vaginal microbiota. Front. Cell. Infect. Microbiol. 2020, 9, 446. [CrossRef] 
31. Bergsson, G.; Arnfinnsson, J.; Karlsson, S.M.; Steingrímsson, O.; Thormar, H. In Vitro inactivation of Chlamydia trachomatis by fatty acids and monoglycerides. Antimicrob. Agents Chemother. 1998, 42, 2290-2294. [CrossRef]

32. Bergsson, G.; Steingrímsson, O.; Thormar, H. In Vitro susceptibilities of Neisseria gonorrhoeae to fatty acids and monoglycerides. Antimicrob. Agents Chemother. 1999, 43, 2790-2792. [CrossRef]

33. Bergsson, G.; Arnfinnsson, J.; Steingrímsson, O.; Thormar, H. In Vitro killing of Candida albicans by fatty acids and monoglycerides. Antimicrob. Agents Chemother. 2001, 45, 3209-3212. [CrossRef]

34. Huang, C.B.; Alimova, Y.; Myers, T.M.; Ebersole, J.L. Short- and medium-chain fatty acids exhibit antimicrobial activity for oral microorganisms. Arch. Oral Biol. 2011, 56, 650-654. [CrossRef]

35. Hayama, K.; Takahashi, M.; Yui, S.; Abe, S. Inhibitory effects of several saturated fatty acids and their related fatty alcohols on the growth of Candida albicans. Drug Discov. Ther. 2015, 9, 386-390. [CrossRef]

36. Jumina, J.; Mutmainah, M.; Purwono, B.; Kurniawan, Y.S.; Syah, Y.M. Antibacterial and antifungal activity of three monosaccharide monomyristate derivatives. Molecules 2019, 24, 3692. [CrossRef]

37. Yao, J.; Rock, C.O. Exogenous fatty acid metabolism in bacteria. Biochimie 2017, 141, 30-39. [CrossRef] [PubMed]

38. Brown, M.A.; Potroz, M.G.; Teh, S.W.; Cho, N.J. Natural products for the treatment of chlamydiaceae infections. Microorganisms 2016, 4, 39. [CrossRef]

39. Ricchi, M.; Odoardi, M.R.; Carulli, L.; Anzivino, C.; Ballestri, S.; Pinetti, A.; Fantoni, L.I.; Marra, F.; Bertolotti, M.; Banni, S.; et al. Differential effect of oleic and palmitic acid on lipid accumulation and apoptosis in cultured hepatocytes. J. Gastroenterol. Hepatol. 2009, 24, 830-840. [CrossRef] [PubMed]

40. Hardy, S.; El-Assaad, W.; Przybytkowski, E.; Joly., E.; Prentki, M.; Langelier, Y. Saturated fatty acid-induced apoptosis in MDA-MB-231 breast cancer cells. A role for cardiolipin. J. Biol. Chem. 2003, 278, 31861-31870. [CrossRef]

41. Rachek, L.I.; Musiyenko, S.I.; LeDoux, S.P.; Wilson, G.L. Palmitate induced mitochondrial deoxyribonucleic acid damage and apoptosis in 16 rat skeletal muscle cells. Endocrinology 2007, 148, 293-299. [CrossRef]

42. Schönfeld, P.; Wojtczak, L. Fatty acids as modulators of the cellular production of reactive oxygen species. Free Radic. Biol. Med. 2008, 45, 231-241. [CrossRef]

43. McQueen, B.E.; Kiatthanapaiboon, A.; Fulcher, M.L.; Lam, M.; Patton, K.; Powell, E.; Kollipara, A.; Madden, V.; Suchland, R.J.; Wyrick, P.; et al. Human fallopian tube epithelial cell culture model to study host responses to Chlamydia trachomatis infection. Infect. Immun. 2020, 88, e00105-20. [CrossRef]

44. Dutow, P.; Wask, L.; Bothe, M.; Fehlhaber, B.; Laudeley, R.; Rheinheimer, C.; Yang, Z.; Zhong, G.; Glage, S.; Klos, A. An optimized, fast-to-perform mouse lung infection model with the human pathogen Chlamydia trachomatis for in vivo screening of antibiotics, vaccine candidates and modified host-pathogen interactions. Pathog. Dis. 2016, 74, ftv120. [CrossRef] 